\title{
Enhancing Social Network Status and Empowerment of Rural Nigerian Women through Non-Formal Education
}

\author{
Loretta C. Ukwuaba, \\ Department of Educational Foundations, \\ Enugu State University of Science and Technology, Enugu, \\ Enugu State, Nigeria \\ Rosemary O. Igbo \\ Department of Continuing Education \& Community Development \\ Ibrahim Badamasi Babangida University, \\ Lapai Nigeria
}

\author{
Doi:10.5901/ajis.2012.v2n5p35
}

\section{Abstract}

The study examined the extent participation in non-formal education programmes improved social networking and empowerment of rural women in Nigeria. One research question and one hypothesis guided the study. Survey research design employing stratified random sampling was used to sample 1668 rural women from Enugu and Plateau States who participated in the Women for Women International's Non-formal Education programme, out of which 1558 responded to the study. Questionnaire was used for data collection. The questionnaire was face validated by experts in the field of education, a reliability co-efficient of 0.76 was obtained using cronbach alfa method of determining internal consistency of instrument. The research question was answered using mean and grandmean while the hypothesis was analysed using t-test statistics. The result revealed that participation in non-formal education programmes improved social network status and empowered rural women in Nigeria. Significant differences existed in the mean response of rural women in Enugu and Plateau states on the extent participation in non-formal education programme improved their social network status. It was recommended among other things that Renewing Women's Lifeskill education prorgamme should be inculcated into women education programme of the National Policy on Women Education in Nigeria

Keywords: Empowerment, Social Networking, Enhancement, Non-formal Education and Rural Women

\section{Introduction}

Enhancement in this study means improving rural women's social network status for their empowerment emphasizing what rural women are gaining through participation in organized non-formal education programmes. In this study also, rural women are women who live in the rural areas of Nigeria, most of them do not have formal education, engages in economic activities that hardly earn them and their families a decent living, have poor health, do not participate in decision making in their families and lack group cohesion. The need to empower women became necessary because of the wide gender gap between men and women globally. Women in many culture the world over are being cheated, discriminated against and relegated to the background, yet the constitute a greater percentage of human population worldwide (Kristf and Wudun, 2009). This situation results in social and economic backwardness of women in the society. The realization of these problems has led to the convening of various international conferences for women in the 20th century. These conferences were held in Mexico 1975, Copenhagen 1980, Nairoba 1985, Rio 1987, Vienna 1993, Cairo 1994 and the Beijing women's conference of 1995. The outcome of these conferences gave rise to taking measures aimed at reversing the ugly trend. United Nations (19950 encouraged all national and 
international development agencies, policy makers, international organization and non-governmental organization to include women's empowerment measures in their programmes. These measures focus among other things on;

- Encouraging women to acquire education both formally, non-formally and informally.

- Eliminating all forms of discrimination against women etc.

In Nigeria, considerable efforts have been made by government as well as non-governmental agencies to implement programmes aimed at the advancement of women. Such programmes like the Better Life for Rural Women's Programme, Family Support Programme, Family Economic Advancement Programme, and most recently the Women for Change Initiative of the wife of the Nigerian President, Dame Patience Jonathan. However, with these programmes in place, the potentials of women particularly rural women are still not fully actualized. Azikiwe (1997) in Zuofa 2008) asserted that social norms, poor incentives, poverty, ignorance and cultural institutions against women in most societies in developing nations are barriers to the advancement of women. In order to encourage women and help them to understand the need to assert their rights in the society, women need power to participate in societal affairs, hence the need for empowerment.

Women empowerment according to Arikpo, Eze and Taiwo (2006) is giving women assess to power over social cultural, psychological and economic situation. Explaining on the concept of women empowerment Mendel-Anonevo (1995) categorized it into four namely: cognitive, psychological, economic and political. The cognitive component of women's empowerment includes women's understanding of their conditions of subordination and causes of such subordination. The psychological components include the development of a feeling that women can act upon to improve their conditions. The economic component requires that women be able to engage in productive activities that will allow them some degree of autonomy and the political component which implies ability to organize and mobilize for change. Women empowerment process therefore must involve not only individual awareness, but collective awareness and action. In the context of this study, women empowerment is a process whereby rural women create social networks both within and outside their communities.

Women for Women International (WFWI) (2009) described social network as a range of support groups and together they form a life safety net to protect individual within the group. WFWI stated further that social networks allows individuals to share ideas, resources and information as well as help to support and protect each other and solve their problems collectively. Individually, women have the ability to acquire knowledge and awareness about their rights, women can advocate for and make changes in their families and communities, however, when many women come together in solidarity to advocate for common needs and desires, their roles are amplified and can carry more weight than a single woman's voice alone (Ukwuaba, 2012). This implies that one woman can change anything, but many women can change everything. Groups and organizations are one of the principal means through which women participate in the life of the society (Karl, 1995). While rural women are poorly represented in the power structure, they have learned to use their avenue to turn their aspiration into actions, thus they frequently form majority of community and grassroots organization and play leading roles in movement for social change. Karl stressed further that women's participation in grassroots organizations is increasingly recognized as critical to their empowerment and as a way for them to help shape their lives.

It has been observed that education is the most effective tool for empowerment of women (Olaleye, 2008). This is true because majority of Nigerian rural women are non-literate (Aderionye, 1997). Igbo (2008) identified non-formal education (NFE) as one of the programmes of adult education which is most probable for empowerment of women, while defining NFE as education or training outside the formal school system. NFE connotes a planned educational activities or training outside the formal school system for any category of people for the purpose of raising their consciousness regarding their social situation and their standard of living (Ngwu,2006). Many reports demonstrated that NFE and other organized interventions given to rural women in their various groups have noteworthy results in their empowerment. WFWI (2009) 
observed that rural women in NFE programmes were able to move about beyond the limits of their household. WFWI stated further that women who had never stepped out of their homes, hardly took part in learning activities outside their home environment now participates in study tours, exposure visits and interactive sessions within learning centres which influence them greatly. Each learning forum brought them out from the village exposing them to alternative ways of being and rural women participation in NFE activities has also exposed them to interact with other women, share ideas and form groups to work collectively to protect them in the patriarchal society (Pants, 2005). Pants further stated that most of these women now take leadership roles in their various social groups and this had increased their confidence.

In a study conducted in rural Bangladesh on the effect of NFE rural credit scheme on empowerment of rural women, Hashemi, Riley and Schuler (1996) observed that rural women who participated in the programme have identity outside their families. The programme gave them socially legitimate reason to move about and to associate with one another in public places and meetings, increased their mobility and visibility exposed them to new ideas and helped them to become more confident and more skillful at interacting in the public sphere. In a similar view, Clark and Gakuru (2002) assess rural women's participation in NFE group activities as an assistance that is indeed supportive in their achievement of personal goals, self confidence, new health behaviour, increased income and increased involvement in family and community activities. When women interact with others outside their families, they share ideas and learn from each other. Empowerment of women is not just an attribute of their robust financial resources, but it is also a function of their membership of organizations and the ample opportunity they have to try new social behaviour.

In as much as there are reports that social networking among women enhances empowerment, researchers like Davis (1996) and Reardon (1995) indicated that there is low networking among rural women in most developing nations. This situation has spurred many international, organizations and nongovernmental organizations to organized NFE learning programmes for women particularly rural women in developing countries like Nigeria. Such organizations like United Nations Development Programme, United Nations Funds for Education of Women (Unifem), World Health Organization (WHO). Others include Development Education Centre (DEC) and Women for Women International (WFWI).

The quest to empower rural women motivated WFWI to educate Nigerian rural women through its NFE programme titled "Renewing women's life skill Education (Renewls)". WFWI is an International Nongovernmental Organization that provides learning empowerment programmes for rural women in Nigeria and other developing nations. The Renewls education programme learning package runs for twelve months and combine right awareness education and vocational skills training. The Renewls learning programmes were launched specifically to ensure that rural women who participated in the programme would have sustainable income, maintain good health, participate in decision making and have improved social network status. WFWI has been educating rural women in two states of Nigeria, Enugu and Plateau states through the Renewls education programme. The Nigerian country director of WFWI made a number of reports which no independent assessor known to these researchers has confirmed, that over 23,000 rural women who participated in the programme in the two states were empowered. In the light of this development, this study was carried out to determine whether participation in Renewls education programme enhanced social network status and empowered rural women in Nigeria.

\section{Purpose of the Study}

The purpose of the study was to determine how participation of Revewls education programme enhanced social network status and empower employment of rural women in Nigeria. Specifically, the study determined the extent to which; 
Renewls education programmes improved the social network status of rural women in Nigeria.

\section{Research Question}

To what extent has Renewls education programme improved the social network status of rural women in Nigeria?

\section{Hypothesis}

In the course of this study a hypothesis was tested at .05 level of significance and an appropriate degree of freedom:

There is no significant difference in the mean response of rural women in Enugu and Plateau states on the extent to which Renewls education programme improved their social network status.

\section{Method}

The design of the study was survey research design because it concentrated on discussing events as they were without any interference on what was observed. The population for the study was 16659 rural women who graduated from the programme from 2007-2010. 10,484 from Enugu State and 6,175 from Plateau State. The researcher used stratified random sampling technique to obtain a sample size of 1668 out of which 1,049 were from Enugu State and 619 from Plateau State.

The instrument for data collection was a 12 -itemed four point scale response option questionnaire, with a response format of very great extent (VGE), great extent (GE), low extent (LE), very low extent (VLE) and a numerical value of 4, 3, 2 and 1 respectively. The instrument was validated by three experts in the field of education, one from measurement and evaluation and two from Adult education. Based on their comments, some items were reconstructed. The reliability of the instrument was determined using Cronbach's alpha formula and internal consistency reliability co-efficient of 0.76 was obtained. The questionnaire was administered to the Renewls programme graduates during their monthly group meetings in their various communities with the help of trained research assistants. The questionnaire served as an interview schedule where respondents experience difficulty in reading and writing. Only 1568 completed questionnaire were returned for analysis.

The research question was analyzed using mean and grand mean, while the hypothesis was tested using t-test statistics at 05 level of significance. The decision rule was as follows: Any item with mean 2.50 and above was accepted which shows that Renewls education programme improved the social network status of rural women in Nigeria to a great extent; while those below 2.50 were not accepted, which indicates that the programme improved the social network status to a low extent. Where the calculated t-value was equal to or greater than the critical value of $t$, the null hypothesis was rejected, but if less than the critical $t$ value, it was not rejected.

\section{Results}

The results of the data analysis were presented in tables according to the research question and hypothesis.

Research Question 
To what extent does Renewls education programme improve the social network status of rural women in Nigeria?

Table 1: Mean rating of rural women in Nigeria on the extent participation in Renewls education programme has improved their social net work status.

$$
\mathrm{N}=1558
$$

\begin{tabular}{|l|l|l|l|l|}
\hline \multicolumn{4}{|l|}{ Because of my participation in Renewls education programme; } & \multicolumn{3}{l|}{ Decision } \\
\hline S/N & ITEMS & $\mathbf{X}$ & SD & Den \\
\hline 1 & I now belong to a social group in my community & 2.95 & 0.94 & G.E \\
\hline 2 & I now discuss with elders and leaders of my community & 2.72 & 1.04 & G.E \\
\hline 3 & I now have access to sources of loan through my social group & 2.85 & 1.04 & G.E \\
\hline 4 & I am now opportune to make new friends & 2.76 & 1.05 & G.E \\
\hline 5 & $\begin{array}{l}\text { I now share experience, ideas and opinion with other women } \\
\text { outside my community }\end{array}$ & 2.85 & 1.06 & G.E \\
\hline 6 & I have visited different places outside my community & 2.89 & 1.05 & G.E \\
\hline 7 & $\begin{array}{l}\text { I can now express myself before other women, outside my } \\
\text { community. }\end{array}$ & 3.00 & 0.94 & G.E \\
\hline 8 & I am now protected from any impending harm by my social group. & 2.87 & 0.95 & G.E \\
\hline 9 & I now discuss women's rights through social group & 2.82 & 1.01 & G.E \\
\hline 10 & $\begin{array}{l}\text { I now belong to different co-operative societies in my } \\
\text { communities. }\end{array}$ & 2.49 & 1.02 & LE \\
\hline 11 & I now have access to women empowerment agencies. & 2.76 & 1.08 & GE \\
\hline 12 & $\begin{array}{l}\text { I have adviced other women on the importance of education } \\
\text { particularly for the girl-child. }\end{array}$ & 2.86 & 1.03 & G.E \\
\hline & Grand Mean & $\mathbf{2 . 8 2}$ & $\mathbf{1 . 0 2}$ & G.E \\
\hline
\end{tabular}

The table shows that a grand mean of 2.82 was obtained. This is an indication that participation in the Renewls education programme has generally improved the social network status of rural women in Nigerian to a great extent.

\section{Testing of Null Hypothesis}

There is no significance difference in the mean response of Enugu State and Plateau State rural women on the extent Renewls education programme has improved their social network states.

Table 2: $\mathrm{t}$ test analysis of significant difference between the mean ratings of rural women in Enugu and Plateau States on the extent Renewls education prorgamme has improved their social network status.

\begin{tabular}{|l|l|l|l|l|l|l|l|}
\hline $\begin{array}{l}\text { Location } \\
\text { of Rural } \\
\text { Women }\end{array}$ & $\mathbf{n}$ & $\mathbf{X}$ & SD & df & t-cal & t-critical & Decision \\
\cline { 1 - 5 } Enugu State & 1030 & 2.99 & 0.98 & 1556 & 6.19 & 1.96 & $\begin{array}{l}\text { Reject } \\
\mathrm{H}_{\mathrm{O}}\end{array}$ \\
\hline Plateau State & 528 & 2.65 & 1.05 & & & \\
\hline
\end{tabular}


The table shows that the calculated $\mathrm{t}$-value is 6.19 and the critical value of $\mathrm{t}$ was 1.96 . Since the calculated value of $t$ was greater than the critical value of $t$, the null hypothesis was rejected. This implies that significant differences exist in the mean ratings of rural women in Enugu and Plateau states regarding the extent to which the Renewls education programme has improved their social network status.

\section{Discussion of Findings}

The findings from the research question revealed that Renewls education programme has improved the social network status of rural women in Enugu and Plateau states Rural women in the two states from the findings now participate in social activities, make new friends both within and outside their communities share ideas and express themselves. This findings are in line with the earlier views of Pants (2005), Clark \& Gakuru (2002) and Hashemi Riley \& Schuler 1996- that participation in NFE programme made rural women interact with women outside their families, share ideas and form groups to work collectively to protect themselves in a patriarchal society. It also assist in women's achievement of personal goals, self confidence, new health behaviour, increased income and increased involvement in family and community activities. However, the impact of the programme on belonging to different cooperative groups was of low extent. This was evidenced in the mean rating of item 10 which is 2.49 . In variably, in as much as rural women participate in group activities; they may be restricted to one or two which may be within the WFWI social network.

The result from the null hypothesis listed at 05 level of significance showed that significant difference exist in the mean ratings of rural women in the two states on the extent to which participation in Renewls education programme has improved their social network status. The finding may be as a result of civil unrest religious and cultural factors in the Plateau state. Women's social activities in most parts of Plateau states were restricted due to civil unrest in the area, unlike their counterpart in Enugu State who were not restricted by any barrier. This was in agreement with the earlier findings by Davis (1996) which revealed the existence of low social networking among rural women in Northern Nigeria. This implies that in as much as rural women in both states participates in Renewls education programmee their level of acquired social network status varies.

\section{Conclusion}

The findings show that participation in Renewls education programme has improved the social network status of rural women in Nigeria. However, the mean ratings of rural women from the two states studied on improved social network status differed significantly due to religious/cultural factors and civil unrest. The findings from this study invariably indicate that improved social network status for empowerment of rural women can be achieved through non-formal education.

\section{Recommendations}

Based on the findings of the study, the following recommendations were made:

1. The Renewls education programme should be adopted as a means of implementing government policy on adult and non - formal education; and ensure that rural women in all the communities in Nigeria participates in the programme to facilitate the realization of the third Millennium Development Goal, which emphasized gender equality and women's empowerment.

2. NFE programmes that can break the excesses of culture and tradition are necessary for positive development of both men and women in the community.

3. Renewls education programme should be inculcated into women's education curriculum as presently stipulated in the National policy on women education in Nigeria. 


\section{References}

Aderionye, R.A. (1997). Literacy education in Nigeria, Ibadan: University of Ibadan Publishing house.

Arikpo, A.B; Eze, J.U. and Taiwo, R.E. (2006). Women empowerment through vocational skill acquisition. Apanacea for poverty reduction, Journal of Nigerian National Council for Adult Education, Vol. 12, 44-51.

Clark, N and Gakuru, O.N. (2002). The effect on health and self confidence in collaborative learning activities, Hygie International Journal of Health Education. 1(2). 102-115.

Davis, P. (1996). The social construction of reality, New York: Anchor

Igbo, R.O. (2008). Adult education and Nigerias development in a globalised world. In R.O. Igbo (ed), Contemporary adult Education: An inclusive approach, Enugu:Cdjap.

Hashemi, S.M; Schuler, R. and Riley, A.P. (1996) Rural credit programme and women's empowerment in Bangladesh. World Development Report 24.235-653.

Kristf, N.D.w and Wudun, S.I. (2009). Half the Sky: Turning oppression into opportunity for rural women world-wide, New York: Prentice Hall.

Mendel-Anonevo, c. (1995). Women, education and empowerment: Pathway towards autonomy, Hambury: Unesco.

Ngwu, P.N.C. (2003). Non-formal education: Concepts and practices, Enugu: Fulladu.

Olaleye, F.O. (2008). Empowering women through education. In M. Boudouvalas and R. Aderionye (eds), Education for Millennium development: Eassy in honour of Prof. M. Omolewa Vol. II, Ibadan: Spectrum books.

Pants, M. (20005). Adult education and poverty reduction: A global priority, International co-operation of German Adult Education Association (112/DVU).

Reardon, B. (1995) Report of USAID-Fund world education/Bamako formal education_ project draft. World education Ind.

Ukwuaba, L.C. (2012). Impact of Renewing Women's Lifeskill (Renewls) education programme on empowerment of rural women in Enugu and Plateau States of Nigeria, Unpublished doctorial dissertation. Department of Educational foundations, Enugu State University of Science and Technology, Enugu.

United Nations (1995). Report from the International Conference on population and development, New York: Author.

Women for Women International (2009). A woman's world: Women for women International renewing women's Lifeskills training manual, Washington DC: Author.

Zuofa, C.C. (2008) Perceieved influence of literacy education on economic empowerment of rural women in Southern Nigeria, Unpublished doctorial dissertation. Department of Educational foundations, Enugu State University of Science and Technology, Enugu. 
